\title{
"BECAUSE" AND GOOD SAMARITANS
}

JAMES E. TOMBERLIN FRANK MCGUINNESS California State University, Northridge

Let $A$ and $B$ be statements of the sorts " $a$ is $F$ " or " $a$ does $\alpha$ ", where $\alpha$ is some action. And read the deontic ought-operator, $O$, as "It ought to be that". Then it is surely true that if $A$ entails $B$, and $O A$, then $O B$. Or, so one might believe. As a reflection of this view, of course, there is the standard deontic principle that if $\vdash A \supset B$, then $\vdash O A \supset O B$. According to some, however, the Good Samaritan Paradox renders this deontic principle unacceptable. Others, finding this principle fundamental, respond by arguing that, in one way or another, alleged instances of the Good Samaritan Paradox are not -after careful scrutiny- genuine. And thus we have a dispute of considerable importance for deontic logic. Now it is not our plan to finally endorse one side of this dispute. Whether the Good Samaritan Paradox is genuine, or whether the above deontic principle is sound, is a matter we happily leave for others to decide. Instead, our aim is to formulate and consider an instance of the Good Samaritan Paradox that, to our knowledge, has been discussed nowhere in the literature. The instance in question is (hopefully) an interesting one. What is more, it may be that this instance defies the sort of treatment applied to familiar cases of the Good Samaritan Paradox. But we anticipate. Before turning to this new case, it should prove helpful to review briefly several of the usual cases as well as standard treatments of same.

\section{The Good Samaritan Paradox: Some Familiar Cases}

Here we construct two (more or less) standard versions of the Good Samaritan Paradox: the first, but not the second, 
employs definite descriptions among its battery of singular terms.

Case I. Bob, we may suppose, is obligated to pay $\mathrm{Al}$ $\$ 500.00$. Despite (or is it because of?) his obligation, however, it turns out that Bob will murder Al one week hence. Putting these bits of information together seems to yield:

(1) It ought to be that Bob pays $\$ 500.00$ to the man he will murder one week hence.

Independently,

(2) Bob pays $\$ 500.00$ to the man he will murder one week hence

entails

(3) Bob will murder a man one week hence.

Of course, (4) is false:

(4) It ought to be that Bob will murder a man one week hence.

Should (1) be true and (2) entail (3), therefore, here is one case where $A$ entails $B$ and $O A$, but $\sim O B$. ${ }^{1}$

Case II. Smith and John share an apartment. One afternoon, while Smith is in his study, John decides to watch television. To John's utter horror, the set goes blank during an interesting program. John rushes to the set and while checking for a faulty tube receives a severe electrical shock. Smith, hearing John's scream, comes to his aid. In the present case, it seems clear that

1 This version of the paradox is due to Hector-Neri Castañeda. See his The Structure of Morality (Springfield, Illinois: Charles C. Thomas Publisher, 1974), pp. 80-82. Castañeda's striking case shows conclusively that the paradox cannot be resolved by restricting the relevant deontic principles to one and the same agent, future actions, and the like. For incisive criticisms of various attempts to resolve the paradox by forcing distinctions concerning agents, patients, times, or places, see $H$. N. Castañeda, "Acts, the Logic of Obligation, and Deontic Calculi," Philosophical Studies, vol. XIX, nos. $1-2$ (1968), 13.26 . 
(5) It ought to be that Smith helps John who has been shocked.

Moreover,

(6) Smith helps John who has been shocked

entails

(7) John has been shocked.

And yet, (8) is false:

(8) It ought to be that John has been shocked.

Once again, then, should (5) be true and (6) entail (7), we have still another case where $A$ entails $B$ and $O A$, but $\sim O B$.

A Familiar Refrain: Scope Ambiguity

We now provide, in capsule form, a standard response to each of the two cases in turn. From the discussion, it will become clear that the general strategy behind each response is essentially the same.

A Critique of Case I. Here it was alleged that (1) is true, (2) entails (3), and yet (4) is false. By way of openers, let us allow that (4) is indeed false. Turn, now, to the claim that (2) entails (3). Among other things, (2) contains a definite description. Notoriously, of course, the exact status of such expressions is anything but settled. To facilitate matters, however, we assume that definite descriptions are Russellian chimeras, to be eliminated in his familiar way. (Still, the cautious reader should satisfy himself that a critique of (1)-(3), similar to the one we provide, is available under any theory of descriptions which recognizes scope distinctions.) With our assumption, the entailment of (3) by (2) is easily accommodated. For (2) becomes

(2a) ( $\exists x)((\forall y)(M y \equiv y=x) \& P x)$,

where " $P x$ " represents " $x$ is paid $\$ 500.00$ by Bob" and 
" $M y$ " represents " $y$ is a man Bob will murder one week hence". (3), in turn, becomes

(3a) $(\exists x)(M x)$.

And, trivially, (2a) entails (3a). What, now, of (1)? A standard answer is that (1) suffers from ambiguity. In parcular, (1) admits of two different readings, each reading dictated by the scope of the ought-operator $O$. If this operator has large scope, (1) must be read as

(la) $O(\exists x)((\forall y)(M y \equiv y=x) \& P x)$.

On the other hand, if this operator takes small scope, (1) should be construed as

(lb) $(\exists x)((\forall y)(M y \equiv y=x) \& O P x)$.

Of the pair (la) and (lb), the latter is no doubt true while the former is surely false (allowing, once more, that (4) is false). Suppose (1) is read as (la). Since (1) so read is false, the fact that (2) entails (3) is perfectly harmless: we do not have a case where $A$ entails $B$ and $O A$, but $\sim O B$. This leaves the reading of $(1)$ as $(1 b)$ for consideration. True enough, under this reading, (1) is acceptable. But with this reading - recall the scope of $O$ in (lb) - what ought to be does not entail (3). And, once again, we fail to have a case where $A$ entails $B$ and $O A$, but $\sim O B$.

$A$ Critique of Case II. Here it was urged that (5) is true, (6) entails (7), but (8) is false. We agree that (8) is false. What is more, we will not quarrel with the suggestion that (6) entails (7). After all, whatever else may be true of (6)'s relative clause "who has been shocked", this expression is presumably adjectival and hence subject to predicative position. And, if so, (6) and (6a) are equivalent:

(6a) (Smith helps John) \& (John has been shocked).

This same equivalence, however, dictates an ambiguity in 
(5). And the ambiguity in question again concerns the scope of the ought-operator $O$. With large scope, (5) becomes:

(5a) $O$ (Smith helps John \& John has been shocked).

But with $O$ taking small scope, the proper reading of (5) is surely

(5b) $O$ (Smith helps John) \& John has been shocked.

Of the pair (5a) and (5b), (5a) is false -if, as agreed, $(8)$ is false - while (5b) is true. When (5) is read as (5a), therefore, (5) is false and there is no paradox: we do not have a case where $A$ entails $B$ and $O A$, but $\sim O B$. Should (5) be read as (5b), it is true. But, owing to the scope of $O$ in $(5 b)$, what ought to be - namely, that Smith helps Johnin no way entails (7). And, once more, there is no paradox.

The goal of both Case I and Case II was straightforward: find a pair of statements $A$ and $B$ such that $A$ does entail $B$, $O A$, but nevertheless $\sim O B$. In turn, we have now sketched fairly standard responses to each case. The general strategy behind each response may be characterized as follows. Search for scope ambiguity in the claim that $O A$. Next, argue that such ambiguity, duly observed, shows that $A$ (when it ought to be) does not entail $B$, on the one hand, while $A$ (when it does entail $B$ ) ought not to be, on the other hand. With our survey done, it is tempting to conclude, as many have concluded, that ambiguity of scope brings about the demise of the Good Samaritan Paradox. But does it really?

\section{A New Case: The Good Samaritan Regained?}

In the present section, we present still another version of the Good Samaritan Paradox. And this new version is then defended against several objections.

Case 111 . Sue is working alone in a local antique shop. Shortly before closing time, a stranger enters and, after robbing the cash register, viciously stabs Sue. Mary, who has a dinner engagement with Sue, arrives outside the shop. Since 
Sue is not outside at the arranged time, Mary checks the front door of the shop. Although the shop appears deserted, the door is unlocked. Concerned, Mary enters and finds Sue helpless on the floor. Mary immediately administers much needed first aid. Here, then, it seems true that

(9) It ought to be that because Sue has been stabbed and only Mary is available to provide help, Mary helps Sue.

Independently, we add that

(10) Because Sue has been stabbed and only Mary is available to provide help, Mary helps Sue

entails

(11) Sue has been stabbed.

And yet, this case concludes, (12) is obviously false:

(12) It ought to be that Sue has been stabbed.

Given that (12) is false, of course, should (9) be true and (10) entail (11), we would indeed have a case where $A$ entails $B, O A$, and $\sim O B$. And, consequently, a defense of the claim that (9) is true as well as the additional claim that (10) entails (11) is surely in order.

Take, first, the claim that (10) entails (11). Now, admittedly, there may be a temptation to read (10) as

(10a) Given that Sue has been stabbed and only Mary is available to provide help, Mary helps Sue.

A little reflection, however, reveals that such a temptation is to be especially avoided. True, (10a) does not entail (11). To see this, just compare (10a) with

(13) Given that today is Wednesday and only the Dodgers and the Mets are idle on Wednesday, the Phillies are scheduled today. 
Any rabid baseball fan knows that (13) may be true even if today is Monday. (13), then, does not entail that today is Wednesday and hence (10a) does not entail (11). But consider :

(14) Because Bill's car ran out of fuel on the turnpike, he called for emergency service.

Surely, we should think, this last statement could not be true if Bill's car did not in fact run out of fuel on the turnpike. And so it is with because statements generally. That is, where $\phi$ and $\psi$ are statements, Because $\phi, \psi$, or equivalently, $\psi$ because $\phi$, entails $\phi$. By this principle, therefore, (10) entails

(15) Sue has been stabbed and only Mary is available to provide help.

Since (15), in turn, entails (11), it follows that (10) likewise entails (11).

What, now, of the claim that (9) is true? Against this claim, there are several likely objections. We present two such objections here along with a reply to each.

First Objection. Of (10) and (10a), it has been properly observed that only the former entails (11). One moral of this crucial difference between (10) and (10a) is that the claim that (9) is true is a sorry piece of confusion. For the distinction between (10) and (10a) carries with it a needed distinction between (9) and (9a):

(9a) $O$ (Given that Sue has been stabbed and only Mary is available to provide help, Mary helps Sue).

Once (9) is contrasted with (9a), this objection continues, it becomes clear that $(9 a)$ is true but (9) is false. With this observation in hand, there is a straightforward solution to Case III. Take (9) first. True enough, what (9) says ought to be -namely, (10) - does entail (11). But fortunately (9) is not true. Turn now to (9a). This statement is true but then what ought to be here in no way entails (11). Accord- 
ingly, we do not have in Case III a genuine situation where $O A, A$ entails $B$, but $\sim O B$.

$A$ Reply. Let us agree that (9) and (9a) are distinct. In addition, we allow that $(9 a)$ is true. Still, why suppose that from the truth of (9a) the negation of (9) follows? After all, it doesn't really follow. Of course, this objection never contended otherwise. Rather, with the contrast between (9) and (9a) noted, this objection invites us to concur that (9) is false. But, in the absence of any argument, such a response to (9) is surely hasty. No, as it stands, the above objection is not at all what the doctor ordered.

Second Objection. Here, it is argued, the contrast between (9) and (9a) is a don't care. Instead, (9) should be regarded as ambiguous. In particular, if the ought-operator $O$ has large scope, (9) is to be represented as

$\left(9^{\prime}\right) O$ (Because Sue has been stabbed and only Mary is available to provide help, Mary helps Sue).

But when $O$ takes small scope, (9) should be read as

$\left(9^{\prime \prime}\right)$ Because Sue has been stabbed and only Mary is avail. able to provide help, $O$ (Mary helps Sue).

Of $\left(9^{\prime}\right)$ and $\left(9^{\prime \prime}\right)$, this objection would have it, the former is false while the latter is true. In order to have a paradox, however, $\left(9^{\prime}\right)$ must be true. That is, due to the scope of $O$ in true $\left(9^{\prime \prime}\right)$, what ought to be in this case does not entail (11). So we may safely dismiss Case III.

$A$ Reply. Well, we can indeed dismiss Case III if $\left(9^{\prime}\right)$ is false. Once again, however, we have been supplied no argument for counting the crucial statement -in this case $\left(9^{\prime}\right)$ - false. After all, the difference between $\left(9^{\prime}\right)$ and $\left(9^{\prime \prime}\right)$ is simply one of scope in the ought-operator. And while such scope distinctions, once observed, appear to handle Case I and II, we should like to know more in the present case. In particular, without some account of "because" constructions, there seems to be no telling reason for finding 
$\left(9^{\prime}\right)$ false but $\left(9^{\prime \prime}\right)$ true. For if, as claimed, $\left(9^{\prime}\right)$ is false when $\left(9^{\prime \prime}\right)$ is true, a proper explanation of this fact will involve a correct (even if partial) analysis of "because" statements. The above objection, therefore, is at best the promise of a solution to Case III. And unless the promise is made good, the Good Samaritan Paradox can hardly be put to rest.

\section{A Conjecture: Scope Ambiguity After All}

In this section, we offer a conjecture concerning the proper treatment of Case III. (A word of caution: We emphasize that what follows is a conjecture; we have no proof that it is really correct.)

According to Case III, it will be recalled, (9) is true, (10) entails (11), but (12) is false. We have allowed that (12) is false. In addition, we argued in the previous section that (10) does entail (11). Suppose this is so. It therefore follows that (9) must be defective if this is not to be a genuine case where $O A, A$ entails $B$, but $\sim O B$. And so the crucial question: Is there such a defect? We think there is. To find it, however, we must look more carefully at "because" statements. For we have urged, so far, only the following principle: Where $\phi$ and $\psi$ are statements, Because $\phi, \psi$ entails $\phi$. Given this principle, (10)'s entailing (11) is secured. By itself, however, this principle provides absolutely no clue as to either (9)'s defect or (more generally) the truth-conditions for "because" statements. And, if we are not mistaken, (9)'s troubles are a direct consequence of the truth-conditions for a certain class of "because" statements. Let us try to explain why.

Recall (14) -the statement that because Bill's car ran out of fuel on the turnpike, he called for emergency service. Now, if this statement is true, we assume, Bill performed the action of calling for emergency service. Should this assumption be agreeable, let us agree as well that (14) -when asserted in appropriate circumstances- purports to explain why Bill performed this action. The class of because state- 
ments we wish to consider, then, are all and only those which purport to explain why statements of the form " $a$ does $\alpha$ " are true, where $a$ is a person and $\alpha$ is some action. For ease of reference, we dub this class $\beta$. Concerning the members of $\beta$, there are several familiar views. One view, associated with A. I. Melden, ${ }^{2}$ is that statements like (14) serve to indicate reasons for actions. (14), then, tells us that Bill's reason for calling for emergency service was his running out of fuel on the turnpike. By this view, moreover, reasons for actions are not causes of those actions. A second view, due to Donald Davidson, ${ }^{3}$ contends that if "because" constructions designed to explain actions are not causal, they are not explanatory at all. Taking such statements as (14) to be explanatory, however, this view proceeds to count reasons for actions as causes of those actions. With this view, then, (14) informs us that Bill's calling for emergency service was caused by his running out of fuel on the turnpike. Now, for our present purposes, we care not whether reasons for actions are causes of those actions. And, thus, we shall not defend one of these two views over the other. We do assume, on the other hand, the following: A statement such as (14) either entails that the fact that Bill's car ran out of fuel on the turnpike is a reason for it to be the case that he called for emergency service (Melden's view), or else (14) entails that the fact that Bill's car ran out of fuel on the turnpike causes it to be the case that he called for emergency service (Davidson's view). More generally, we assume: If Because $\phi, \psi$ belongs to the class $\beta$, then Because $\phi, \psi$ entails $\phi / \psi$ where " $\phi / \psi$ " is just convenient shorthand for the locution "either the fact that $\phi$ is a reason for it to be the case that $\psi$, or else the fact that $\phi$ causes it to be the case that $\psi "$ '. Of course, we already have the principle that Because $\phi, \psi$ entails $\phi$. To this principle, we now add that Because $\phi, \psi$ likewise entails $\psi$. And we are finally in posi-

2 See his Free Action (New York: Humanities Press, 1961).

3 "Actions, Reasons, and Causes," Journal of Philosophy 60 (1963), 685-700. 
tion to offer a rule of truth for members of the class $\beta$. Our proposal:

(16) Where Because $\phi, \psi$ belongs to $\beta$, Because $\phi, \psi$ is true if and only if (a) $\phi$ is true, (b) $\psi$ is true, and (c) $\phi / \psi$ is true.

In a word, (16) takes conditions (a), (b), and (c) to jointly exhaust the truth-conditions for members of $\beta$. Given our previous remarks, we believe that this is indeed the case. With these details done, we turn now to the status of (9).

Taken at face value, (9) would have it that $O(10)$. And (10) entails that Mary performs the action of helping Sue. Moreover, (10) —when asserted in appropriate circumstances - purports to explain why Mary performed this action. It follows therefore that $(10)$ is a member of class $\beta$. From this and the rule of truth embodied in (16), then, (10) and (17) are equivalent:

(17) ((Sue has been stabbed and only Mary is available to provide help) \& (Mary helps Sue)) \& (Sue has been stabbed and only Mary is available to provide help/ Mary helps Sue).

Since (17) is a rather complex conjunction, we may reasonably expect (9) to be troubled with ambiguity. In particular, if (9)'s deontic operator takes large scope, (9) becomes the claim:

$\left(9_{1}\right) O(17)$.

But if this operator takes smaller scope, then, owing to the complexity of (17), there are a number of different readings for (9). Of these various readings, the one most pressing is presumably $\left(9_{2}\right)$ :

$\left(9_{2}\right)$ (Sue has been stabbed and only Mary is available to provide help) \& ( $O$ ((Mary helps Sue) \& (Sue has been stabbed and only Mary is available to provide help/Mary helps Sue)) ). 
(We will not discuss any of the remaining readings of (9). But it will become clear that these other readings do not affect our general assessment of (9) and Case III.) Let us consider these two readings in reverse order.

Of $\left(9_{2}\right)$, not much needs to be said. Indeed, we cheerfully grant that $\left(9_{2}\right)$ is true. But the situation is otherwise with $\left(9_{1}\right)$. For this statement is surely false, if (as we have agreed) statement $(12)$ is false. Why so? Because $\left(9_{1}\right)$ says that a conjunction ought to be, one conjunct of which is (11). And, if (12) is false, (11) ought not to be. If (11) ought not to be, therefore, the conjunction of (11) with the rest of (17) ought not to be either. With the status of $\left(9_{1}\right)$ and $\left(9_{2}\right)$ decided, we are now in position to assess Case III. (9) is ambiguous as between false $\left(9_{1}\right)$ and true $\left(9_{2}\right)$. Suppose $\left(9_{1}\right)$ is the reading of (9). To be sure, what ought to be according to $\left(9_{1}\right)$ entails (11). But (9) so read is false. Suppose, then, that we read (9) as (9.). So read, of course, (9) is true. But what ought to be in this case -observe the scope of $\left(9_{2}\right)$ 's deontic operator- does not entail (11). With our analysis of (9) and (10), therefore, Case III fails after all.

\section{Concluding Remarks}

We opened this paper with a survey of several standard versions of the Good Samaritan Paradox along with the usual treatments of same. These standard versions of the paradox are seemingly beset by scope ambiguity. Next, we formulated a nonstandard version of the Good Samaritan: Case III. At first blush, this case escaped any charge of scope ambiguity. Moreover, it threatened to be a genuine case where, for some statements $A$ and $B, O A, A$ entails $B$, but $\sim O B$. By way of conjecture, we then offered a critique of this case. And the upshot of our proposal is that Case III succumbs to ambiguity of scope, after all. This verdict, of course, hinges upon our conjectured analysis of a certain class of "because" statements. Should this analysis be correct, cases such as Case III pose no problem for deontic logic. But if our analy- 
sis proves to be mistaken, it may very well be that the Good Samaritan Paradox remains alive because of "because"."

4 We are grateful to Bruce Aune, Sidney Luckenbach, Jeffrey Sicha, and John Tienson for valuable advice and criticism. We are particularly indebted to Aune for prodding us to arrive at our analysis of Case III, and to Tienson for correcting a mistake in that analysis.

of the currently available deontic machineries, there is (to the best of our knowledge) only one capable of treating our "because" version of the paradox: the deontic system developed by Hector-Neri Castanieda in his "On the Semantics of the Ought-to-do," Synthese, vol. 21 (1970): 449.468, and Thinking and Doing: The Philosophical Foundations of Institutions (Dordrecht: D. Reidel Publishing Co., 1975), chs. 7 and 9. There are fundamental differences, however, between the analysis Castañeda would offer and our own. For example, his system requires a distinction between propositions and practitions; the former have truth-values while the latter do not. Moreover, for Castañeda, deontic operators always apply to practitions (open or closed), yielding propositions. In our analysis, we have deliberately assumed that deontic operators always apply to propositions (open or closed); and, consequently, we do not require Castañeda's complicating (and we believe unnecessary) distinction between propositions and practitions. There are other crucial differences as well. But, without worrying over the various details here, we invite the reader to compare our analysis against the one dictated by posing our "because" case within Castañeda's system. 
Sean $A$ y $B$ enunciados de cualquiera de los tipos " $a$ es $F$ " o bien " $a$ hace $\alpha$ ". Y léase el operador deóntico de deber, $O$, de la siguiente manera "Debe ser que". Entonces es ciertamente tentador suponer que si $A$ implica formalmente a $B$, y $O A$, entonces $O B$. Como un reflejo de esta opinión tenemos, claro está, el principio de la lógica deóntica standard de que si $\vdash A \supset B$, entonces $\vdash O A \supset O B$. Se ha argumentado, sin embargo, que diversos casos de la Paradoja del Buen Samaritano — casos en los que, supuestamente, para algunos enunciados $A$ y $B, A$ implica formalmente a $B, O A$ y, sin embargo $\sim O B$ - muestran que es incorrecto el anterior principio deóntico.

El propósito del presente artículo es, en pocas palabras, formular una nueva versión de la Paradoja del Buen Samaritano, versión que (hasta donde sabemos) no se ha discutido en la literatura sobre el tema. Esta nueva versión, que gira en torno a la muy notoria noción de porque, se compara y contrasta críticamente con versiones anteriores, más standard, de la paradoja; inicialmente se la defiende, entonces, en contra de diversas objeciones; y, finalmente, se propone una solución tentativa que apela a nuestro análisis de cierta clase de enunciados "porque".

Nuestra nueva versión de la paradoja puede presentarse de la siguiente manera: Susana trabaja en una tienda de antigüedades de la localidad y está sola. Poco antes de cerrar, un sujeto extraño entra, vacía la caja de dinero y apuñala sin piedad a Susana. María, quien iba esa noche a cenar con Susana, llega al exterior de la tienda. Puesto que Susana no se encuentra alli a la hora convenida, María revisa la puerta de entrada. Aun cuando la tienda parece estar completamente vacía, la puerta no está cerrada. Preocupada, María entra y encuentra a Susana tendida en el piso y de inmediato le adminis. tra los muy necesarios primeros auxilios. Aquí, parecería que $A$ implica formalmente a $B$ :

$A$ : Porque Susana ha sido apuñalada y sólo María puede auxiliarla, María ayuda a Susana.

$B$ : Susana ha sido apuñalada.

Además, es tentador mantener que $O A$ pero $\sim O B$. De esta manera surge un problema agudo: después de todo ¿es éste un contraejemplo genuino a un principio deóntico ampliamente aceptado? 
Para responder a esto, nuestra propuesta es que es preciso considerar las condiciones de verdad de cierta clase de enunciados "porque". Los enunciados "porque" en cuestión son todos y sólo aquéllos que - cuando se afirman en las condiciones apropiadas - pretenden ser una explicación de por qué son verdaderos enunciados de la forma " $a$ hace $\alpha$ ", donde $a$ es una persona y $\alpha$ es alguna acción. Llamemos a esta clase (de enunciados "porque") $\beta$. Entonces, proponemos:

Donde Porque $\phi, \psi$ pertenece a $\beta$, Porque $\phi, \psi$ es verdadero si y sólo si (a) $\phi$ es verdadero, (b) $\psi$ es verdadero, y (c) $\phi / \psi$ es verdadero (donde " $\phi / \psi$ " es una abreviatura conveniente para la expresión disyuntiva "o bien el hecho de que $\phi$ es una razón para que suceda que $\psi$ o bien el hecho de que $\phi$ es la causa de que suceda que $\psi "$ ).

Equipados de esta manera, criticamos nuestra versión "porque" de la Paradoja del Buen Samaritano de la siguiente forma. La oración "Debe ser que $A$ " es ambigua y puede leerse de alguna de las siguientes dos formas:

$A 1: O$ (( (Susana ha sido apuñalada y sólo María puede auxiliarla) \& (María ayuda a Susana)) \& (Susana ha sido apuñalada y sỏlo María puede auxiliarla/María ayuda a Susana))).

y

A2: (Susana ha sido apuñalada y sólo María puede auxiliarla) \& ( $O$ ( (María ayuda a Susana) \& (Susana ha sido apuñalada y sólo María puede auxiliarla/María ayuda a Susana))./

De éstas, $A 2$ es sin duda verdadera mientras que $A 1$ es ciertamente falsa. Supongamos que "Debe ser que $A$ " se lee de la manera $A 1$. Claro está que lo que de acuerdo con $A 1$ debería ser, implica formalmente a $B$. Pero "Debe ser que $A$ ", así leída, es falsa y no hay paradoja. Por otra parte, supongamos que leemos "Debe ser que $A$ " como $A 2$. Es claro que así leida "Debe ser que $A$ " es verdadera. Pero lo que en este caso debe ser -obsérvese el alcance del operador deóntico de $A 2$ - no implica formalmente a $B$. Y así, una vez más, no hay paradoja.

(Resumen de James E. Tomberlin y Frank McGuinness) 